\title{
Effect of Heat Pretreatment on Mesophilic Methane Fermentation of Food Refuse in Municipal Solid Waste
}

\author{
YUKI IKEDA ${ }^{1}$, YOSHIHIKO KURAHASHI ${ }^{2}$ KOHJI NAKAMURA ${ }^{2}$, TADAAKI MORI $^{2}$, \\ and TOSHINORI KAMEOKA ${ }^{3}$
}

\author{
${ }^{1}$ Sonne-Frau Environmental Research / 877-3 Fukainaka-machi, Sakai City, Osaka, 599-8272, Japan \\ ${ }^{2}$ Moriplant Co., Ltd. / 2-2-3 Showa-cho, Abeno-ku, Osaka, 545-0011, Japan \\ ${ }^{3}$ Institute of Livestock Industry's Environmental Technology, \\ Livestock Industry's Environmental Improvement Organization \\ /1 Odakurahara, Oazaodakura, Nishigou-mura, Nishishirakawa-gun, Fukushima, 961-8061, Japan
}

\begin{abstract}
The heat pretreatment conditions of food refuse such as leftover food collected from restaurants were examined to improve the gas production efficiency in the mesophilic methane fermentation. In the bench-scale continuous experiment of the mesophilic methane fermentation at the VS loading rate of $2.5 \mathrm{~kg}-\mathrm{VS} / \mathrm{m}^{3} / \mathrm{day}$ and the HRT of 29 days, the VS removal was improved and the gas production per influent VS increased by $19 \%$ with the heat pretreatment. The methane content of produced gas was $68 \%$ and there was no difference from that obtained from the control test using non-heat-treated waste. The methane yield per removed VS and the efficiency of carbon conversion to methane were also improved significantly with the heat pretreatment. The measured gas production yield and methane content with the heat pretreatment were notably greater than the theoretically calculated value estimated by the approximate molecular formula and the stoichiometric equation reported to agree well with the experimental results in thermophilic methane fermentation on organic matters in municipal solid waste. The trial calculation results of the energy balance showed that the amount of power generation and available thermal energy can be increased even after compensating the heat required for the pretreatment of waste.
\end{abstract}

Key words: heat pretreatment, mesophilic methane fermentation, food refuse, methane yield, heat balance

\section{INTRODUCTION}

Recently, energy production by means of methane fermentation has been recognized as an effective way to reuse the organic fraction of municipal solid waste in Japan. Thermophilic methane fermentation is considered highly effective process because of its high solid loading rate and short hydraulic retention time (HRT). It should be noted, however, that this process requires more energy to heat the fermentation process, discharges the digestion liquor with poor qualities, and is unstable especially under the high concentration of ammonia, as compared with the mesophilic process.

Li et $a l .{ }^{1)}$ compared the mesophilic and thermophilic processes in the anaerobic digestion of organic fraction of municipal solid waste (with addition of ferrous, nickel and cobalt chloride) with HRT of 5 to 30 days, and the VS volumetric loading rate of 2.95 to $17.6 \mathrm{~kg} / \mathrm{m}^{3} /$ day using a semi-continuous flow fully-mixed reactor, and reported the 
following results:

(1) Stable operation was achieved both in the mesophilic and the thermophilic digestion processes with HRT as short as 5 days.

(2) There was no significant difference between mesophilic and thermophilic digestion with HRT longer than 15 days in terms of the VS reduction and the methane production.

(3) The organic decomposition rate of the thermophilic process was about $10 \%$ greater than that of the mesophilic process with HRT less than 10 days.

(4) The VFA concentration in the digestion liquor of mesophilic digestion was low (around $180 \mathrm{mg} / l$ ) under any HRTs, while that of thermophilic digestion was higher and ranges from 2000 to $4760 \mathrm{mg} / l$. This was due to the residual propionic acid and acetic acid resulting from the faster hydrolysis of thermophilic digestion.

(5) At any HRTs, the soluble BOD and COD of the thermophilic digestion liquor are several times higher than those of the mesophilic digestion. The soluble BOD and COD concentrations in the mesophilic digestion liquor were reduced with the increased HRT. For example, they decreased to about half, as HRT changes from 5 to 30 days.

The above results indicate that it is possible to operate the thermophilic digestion with shorter HRT because of its fast hydrolysis, although considerable portion of the solid remains without fully being methanized in the digestion liequor. On the other hand, the mesophilic methane fermentation has a slower hydrolysis but can gasify the hydrolyzed compounds to lower concentrations. As a result, BOD and COD of the digestion liquor of mesophilic methane fermentation are low. This is one of the advantages of the mesophilic methane fermentation, because the load to the following water treatment facility, as well as the total treatment cost, strongly depends on the qualities of digestion liquor. Therefore, we might be able to take the advantage of the mesophilic fermentation, if the rate of hydrolysis could be improved.

In this paper we examined the effect of heating as a method of pretreatment of the waste to improve the efficiency of the mesophilic methane fermentation. We also examined the effectiveness of the mesophilic methane fermentation with the heat pretreatment of food refuse in municipal solid waste from the view points of methane yield and carbon conversion efficiency.

\section{MATERIALS AND METHODS}

The study consists of two preliminary experiments to determine the conditions of heat pretreatment and a continuous methane fermentation experiment of food refuse with and without the heat pretreatment.

Preparation of food refuse in municipal solid waste In the preliminary experiments, a commercial box lunch was mixed with an equal weight of tap water, and homogenized by a blender. The resultant mixture was used as the raw wastewater.

$\mathrm{Li}$ et $a l .^{2}{ }^{2}$ studied the effect of the TS concentration on the thermophilic methane fermentation of the organic fraction of municipal solid waste, and reported that the TS concentration around $10 \%$ or less is desirable for the stable operation of the reactor and for the energy production efficiency. Also a pump used for the continuous experiment could be operated with the TS concentration of $10 \%$ or less. Therefore the raw wastewater for the continuous experiment was made from a leftover food collected from restaurants and dilution water so that the TS concentration is $10 \%$ or less. The characteristics of raw wastewater samples are shown in Table 1.

Table 1 Characteristics of raw wastewater

\begin{tabular}{c|c|c}
\hline & $\begin{array}{c}\text { Preliminary } \\
\text { experiment }\end{array}$ & $\begin{array}{c}\text { Continuous } \\
\text { experiment }\end{array}$ \\
\hline $\mathrm{pH}$ & & 5.3 \\
\hline $\mathrm{TS}\left(\mathrm{kg} / \mathrm{m}^{3}\right)$ & 185 & 88.1 \\
\hline $\mathrm{VS}\left(\mathrm{kg} / \mathrm{m}^{3}\right)$ & 159 & 74.5 \\
\hline $\mathrm{SS}\left(\mathrm{kg} / \mathrm{m}^{3}\right)$ & & 65.1 \\
\hline $\mathrm{COD}\left(\mathrm{kg} / \mathrm{m}^{3}\right)$ & & 108.0 \\
\hline $\mathrm{T}-\mathrm{N}\left(\mathrm{kg} / \mathrm{m}^{3}\right)$ & & 4.2 \\
\hline $\mathrm{T}-\mathrm{P}\left(\mathrm{kg} / \mathrm{m}^{3}\right)$ & & 0.85 \\
\hline
\end{tabular}


Preliminary experiment [1] The ultra pure dialysis tubes (Invitrogen Co., Carlsbad, CA, USA) were filled with $10 \mathrm{~g}$ of the raw wastewater with three sets of pretreatment conditions:(1)no heat treatment (control), (2) heat treatment at $110^{\circ} \mathrm{C}$ for $30 \mathrm{~min}$, (3) heat treatment at $110{ }^{\circ} \mathrm{C}$ for $60 \mathrm{~min}$ ), and immersed in distilled water at room temperature for $24 \mathrm{~h}$. Then, the weights of tubes were measured after the elution.

\section{Preliminary experiment [2] Fed $100 \mathrm{ml}$} of the raw wastewater with four sets of pretreatment conditions: (1)no heat treatment (control), (2) heat treatment at $80^{\circ} \mathrm{C}$ for $30 \mathrm{~min}$, (3) heat treatment at $100{ }^{\circ} \mathrm{C}$ for 30 min, (4) heat treatment at $120^{\circ} \mathrm{C}$ for $30 \mathrm{~min}$ ) to the fermentation reactor (volume: $8 l$, continuously mixed) with $6 l$ of the anaerobic sludge and maintained at $35{ }^{\circ} \mathrm{C}$. During the batch fermentation of the wastewater, the amount of gas produced in $24 \mathrm{~h}$ was measured using a gas meter.

Continuous methane fermentation experiment Figure 1 shows a schematic diagram of the heat pretreatment and methane fermentation system used in the continuous experiment. The reactor was of special construction with an intermittent mixing to obtain the sludge retention time (SRT) longer than the HRT. The thermally insulated reactor (effective volume: $1.47 \mathrm{~m}^{3}$ ) was filled with the anaerobic sludge and maintained at $35{ }^{\circ} \mathrm{C}$. The influent flow rate was maintained at 50l/day for the HRT of 29.4 days. The raw wastewater was supplied to the reactor every other hour. The reactor mixer was operated intermittently when the

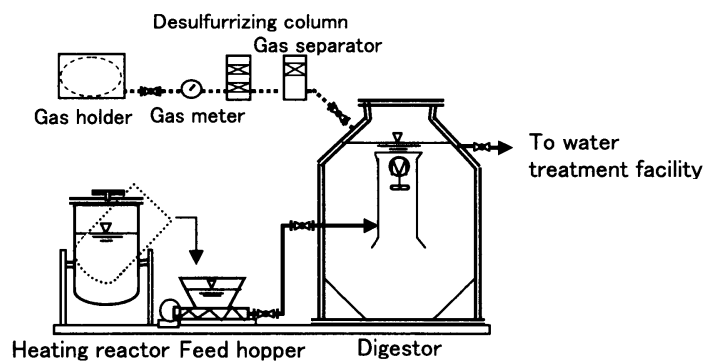

Fig. 1 Schematic diagram of heat pretreatment and methane fermentation system raw wastewater is supplied, heat is supplied by the boiler. The amount of gas production became almost constant after acclimatization for about a month. Then the characteristics of the raw wastewater and digestion liquor, and the amount and the characteristics of produced gas were measured for six days. The same experiment using the raw wastewater with the heat pretreatment (100 ${ }^{\circ} \mathrm{C}$ for $30 \mathrm{~min}$ ) was also conducted.

Anaerobic sludge Anaerobic sludge used as the seed for the fermentation experiments was collected at an actual mesophilic methane fermentation reactor of Kanki Industry Co., Ltd. that treats kitchen garbage. The experiment was carried out after maintaining the sludge for one week at $35^{\circ} \mathrm{C}$ without applying the loading.

Analytical methods $\mathrm{pH}, \mathrm{COD}, \mathrm{TS}, \mathrm{VS}$ and SS were determined according JIS K 0102 $-1998^{3)}$. After moisture condensation and desulfurization, the concentration of carbon dioxide in the produced gas was measured by using Kitagawa Gas Detector Tube System (Komyo Rikagaku Kogyo K.K., Tokyo, Japan) and the remaining portion of the gas was considered as methane. The carbon and hydrogen contents were determined by the combustion tube method and the nitrogen content was determined by the Kjeldahl method. ${ }^{4)}$

\section{Trial calculation of the energy balance}

A trial calculation of the energy balance with a reactor of effective volume of $3000 \mathrm{~m}^{3}$ during the winter for the mesophilic methane fermentation of the food refuse with and without the heat pretreatment was made based on the experimental results.

\section{RESULTS AND DISCUSSION}

Preliminary experiment [1]: Heating condition and elution rate The results of preliminary experiment [1] are shown in Table 2. Compared with the control experiment (without the pretreatment), the mass of materials eluted from the dialysis tubes increased by $10.5 \%$ and $11.2 \%$ when pretreated at $110^{\circ} \mathrm{C}$ for $30 \mathrm{~min}$ and $60 \mathrm{~min}$, respectively. Because the dialysis tube used 
in the experiment is designed to pass the molecules with molecular weight of 3000040000 or smaller, the results imply that a part of organic matters with large molecular sizes in the raw wastewater were converted to smaller molecules by the pretreatment. Since no significant difference was observed between the pretreatment durations of 30 min and $60 \mathrm{~min}$, it was suggested that the elution rate, or the molecular size reduction, is not dependent on the pretreatment duration longer than $30 \mathrm{~min}$.

\section{Preliminary experiment [2]: Gas produc-} tion yield in batch fermentation The gas production yields at the different pretreatment temperatures in the batch fermentation are shown in Table 3. The TS loading rate was $3.10 \mathrm{~kg}-\mathrm{TS} / \mathrm{m}^{3} /$ day $\left(2.65 \mathrm{~kg}-\mathrm{VS} / \mathrm{m}^{3} /\right.$ day $)$. Gas productions per influent VS increased by 12 to $22 \%$ depending upon the pretreatment temperatures. The maximum yield of $22 \%$ was observed at $100^{\circ} \mathrm{C}$.

The effects of heat pretreatment in continuous fermentation Results of the continuous experiment of mesophilic methane fermentation are summarized in Table 4. The

Table 2 Elution weight from dialysis tube

\begin{tabular}{l|c|c}
\hline $\begin{array}{l}\text { Heat treatment } \\
\text { condition }\end{array}$ & $\begin{array}{c}\text { Elution } \\
\text { Weight }(\mathrm{mg})\end{array}$ & $\begin{array}{c}\text { Ratio to } \\
\text { control }\end{array}$ \\
\hline $\begin{array}{l}\text { No heat treatment } \\
\text { (control) }\end{array}$ & 119.9 & 1.00 \\
\hline $\begin{array}{l}\text { Heat pretreatment } \\
\text { at } 110^{\circ} \mathrm{C} \text { for } 30 \mathrm{~min}\end{array}$ & 132.5 & 1.11 \\
\hline $\begin{array}{l}\text { Heat pretreatment } \\
\text { at } 110^{\circ} \mathrm{C} \text { for } 60 \mathrm{~min}\end{array}$ & 133.3 & 1.11 \\
\hline
\end{tabular}

Table 3 Gas production in batch type methane fermentation

\begin{tabular}{l|c|c}
\hline $\begin{array}{l}\text { Heat pretreatment } \\
\text { condition }\end{array}$ & $\begin{array}{c}\text { Gas production yield } \\
\left(\mathrm{m} l / \mathrm{g}-\mathrm{VS}_{\text {influen }}\right)\end{array}$ & $\begin{array}{c}\text { Ratio to } \\
\text { control }\end{array}$ \\
\hline $\begin{array}{l}\text { No heat treatment } \\
\text { (control) }\end{array}$ & 730 & 1.00 \\
\hline $\begin{array}{l}\text { Heat pretreatment } \\
\text { at } 80^{\circ} \mathrm{C} \text { for } 30 \mathrm{~min}\end{array}$ & 815 & 1.12 \\
\hline $\begin{array}{l}\text { Heat pretreatment } \\
\text { at } 100^{\circ} \mathrm{C} \text { for } 30 \mathrm{~min}\end{array}$ & 890 & 1.22 \\
\hline $\begin{array}{l}\text { Heat pretreatment } \\
\text { at } 120^{\circ} \mathrm{C} \text { for } 30 \mathrm{~min}\end{array}$ & 840 & 1.15 \\
\hline
\end{tabular}

Volumetric loading rate $: 2.65 \mathrm{~kg}-\mathrm{VS} / \mathrm{m}^{3} /$ day
VS loading rate and HRT were $2.53 \mathrm{~kg}^{-}$ $\mathrm{VS} / \mathrm{m}^{3} /$ day and 29.4 days, respectively. The VS removal efficiency and the gas production yield per influent VS were $71 \%$ and $0.69 \mathrm{~m}^{3} / \mathrm{kg}$ -VS, respectively, on the raw wastewater without the pretreatment. Thus, the gas production per VS removed was calculated to be $0.97 \mathrm{~m}^{3} / \mathrm{kg}$-VS.

With the pretreatment, the VS removal efficiency and the gas production yield per influent VS were improved to $75 \%$ and $0.82 \mathrm{~m}^{3} / \mathrm{kg}-\mathrm{VS}$, respectively. The gas production per VS removed was $1.09 \mathrm{~m}^{3} / \mathrm{kg}-\mathrm{VS}$, which was an improvement by $19 \%$ over the experiment without the heat pretreatment. The methane content in the gas produced was $68 \%$ in either case.

These results suggest that the fraction of organic matters that can not be readily hydrolyzed by the mesophilic fermentation system could be reduced by the heat treatment, and had resulted in the enhancement of gas production yield.

Methane yield and carbon conversion efficiency In the continuous fermentation experiments, the methane yields per VS removed with and without pretreatment were $0.74 \mathrm{~m}^{3} / \mathrm{kg}$-VS and $0.66 \mathrm{~m}^{3} / \mathrm{kg}$-VS, respectively (Table 5). Reported data on thermophilic methane fermentation of synthetic municipal solid waste ${ }^{5,6)}$ are lower than these values as shown in Table 5.

The average carbon content in the raw

Table 4 Methane fermentation performance in continuous experiment

\begin{tabular}{|c|c|c|c|}
\hline & & \begin{tabular}{|c|} 
With heat \\
pretreatment
\end{tabular} & $\begin{array}{c}\text { No heat } \\
\text { pretreatment }\end{array}$ \\
\hline \multicolumn{2}{|l|}{ HRT (day) } & \multicolumn{2}{|c|}{29.4} \\
\hline \multirow{2}{*}{$\begin{array}{l}\text { Volumetric } \\
\text { loading rate }\end{array}$} & $\mathrm{kg}-\mathrm{TS} / \mathrm{m}^{3} /$ day & \multicolumn{2}{|c|}{3.0} \\
\hline & $\mathrm{kg}-\mathrm{VS} / \mathrm{m}^{3} /$ day & \multicolumn{2}{|c|}{2.53} \\
\hline \multicolumn{2}{|c|}{$\mathrm{pH}$ of the digested liquor } & 7.8 & 7.8 \\
\hline \multicolumn{2}{|c|}{ TS removal (\%) } & 62 & 62 \\
\hline \multicolumn{2}{|c|}{ VS removal (\%) } & 75 & 71 \\
\hline \multicolumn{2}{|c|}{ SS removal (\%) } & 67 & 66 \\
\hline \multirow{3}{*}{$\begin{array}{l}\text { Gas } \\
\text { production }\end{array}$} & $\mathrm{m}^{3} /$ day & 3.08 & 2.56 \\
\hline & $\mathrm{m}^{3} / \mathrm{kg}-\mathrm{VS}_{\text {influent }}$ & 0.82 & 0.69 \\
\hline & $\mathrm{m}^{3} / \mathrm{kg}^{-\mathrm{VS}_{\text {remove }}}$ & 1.09 & 0.97 \\
\hline \multicolumn{2}{|c|}{$\mathrm{CH}_{4}$ content in biogas $(\%)$} & 68 & 68 \\
\hline
\end{tabular}


Table 5 Gas production, methane yield and carbon conversion efficiency

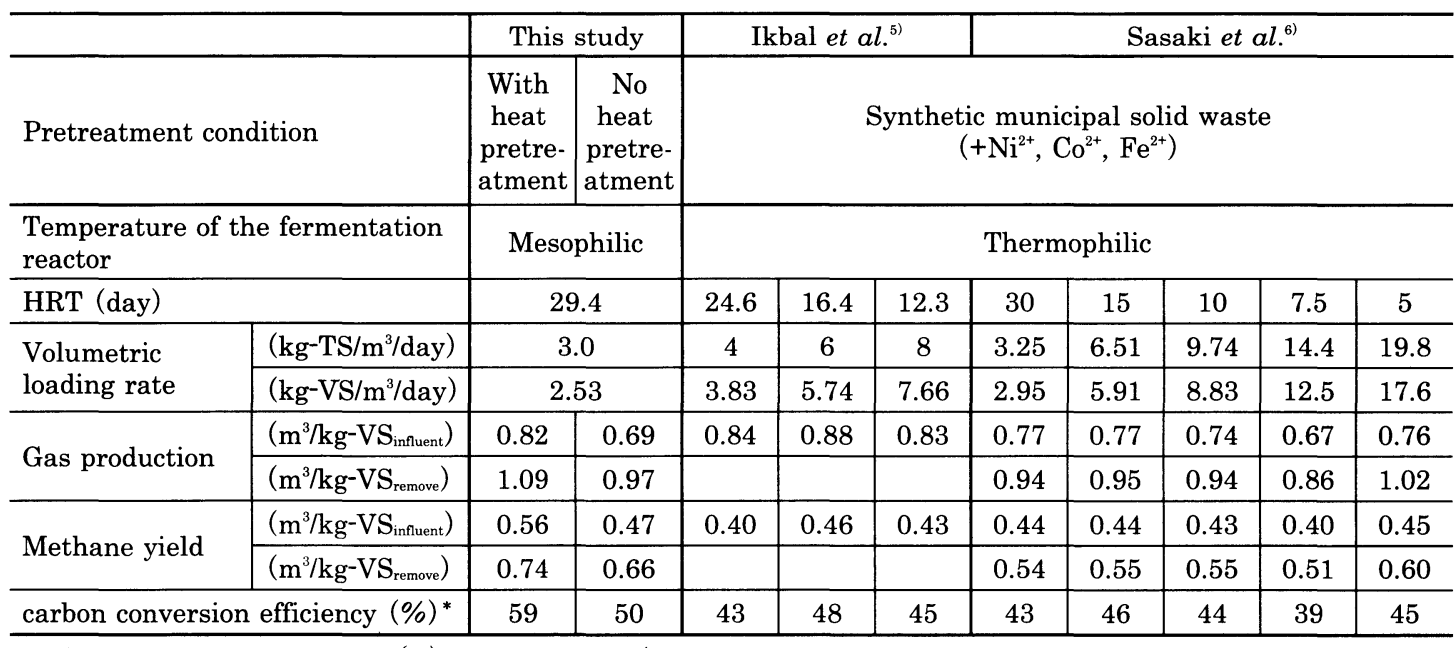

$*$ Carbon conversion efficiency $(\%)=$ Carbon in $\mathrm{CH}_{4} /$ Carbon in raw waste $\times 100$

wastewater used in the study was $42.9 \%$. Carbon conversion efficiencies observed with and without pretreatment were $59 \%$ and $50 \%$, respectively. The reported carbon conversion efficiencies in the thermophilic system are 43 to $48 \%$ (Table 5 ).

Characteristics of gas produced and stoichiometry Sasaki et $a l .^{6)}$ reported that the following stoichiometric equation agrees well with experimental results obtained in thermophilic methane fermentation on organic matters in municipal solid waste.

\section{$\mathrm{C}_{17} \mathrm{H}_{29} \mathrm{O}_{10} \mathrm{~N}+6.5 \mathrm{H}_{2} \mathrm{O} \rightarrow$}

$9.25 \mathrm{CH}_{4}+6.75 \mathrm{CO}_{2}+\mathrm{NH}_{4}^{+}+\mathrm{HCO}_{3}^{-}$

Okuno et $a l .^{7)}$ reported that the gas production and methane content in the gas produced in thermophilic methane fermentation on municipal solid waste and night soil treatment sludge can be estimated by the following general equation.

$$
\begin{aligned}
\mathrm{C}_{\mathrm{n}} \mathrm{H}_{\mathrm{a}} \mathrm{O}_{\mathrm{b}} \mathrm{N}_{\mathrm{c}}+(\mathrm{n}-0.25 \mathrm{a}-0.5 \mathrm{~b}+1.75 \mathrm{c}) \cdot \mathrm{H}_{2} \mathrm{O} \\
\quad \rightarrow(0.5 \mathrm{n}+0.125 \mathrm{a}-0.25 \mathrm{~b}-0.375 \mathrm{c}) \cdot \mathrm{CH}_{4} \\
\quad+(0.5 \mathrm{n}-0.125 \mathrm{a}+0.25 \mathrm{~b}-0.625 \mathrm{c}) \cdot \mathrm{CO}_{2} \\
\quad+\mathrm{cNH}_{4}{ }^{+}+\mathrm{cHCO}_{3}{ }^{-}
\end{aligned}
$$

where, $n, a, b$, and $c$ are the numbers of carbon, hydrogen, Oxygen, and nitrogen atoms in the approximate molecular formula, respectively.

The average elementary composition of solid in the raw wastewater was C: $42.9 \%$, $\mathrm{H}: 6.8 \%$, O:30.2\%, and N:4.7\%, which corresponds to the approximate molecular formula of $\mathrm{C}_{11} \mathrm{H}_{20} \mathrm{O}_{6} \mathrm{~N}$. The gas production yield and methane content estimated by the molecular formula and the above-mentioned stoichiometric equation are summarized in Table 6. It should be noted that both of the measured gas production yield and the methane content are greater than the theoretical values. The greater methane content is not due to the dissolution of carbon dioxide in the gas produced and dissociation to hydrogencarbonate ion in digestion liquor. Because, the concentration of hydrogencarbonate ion dissociated from carbonic acid is approximately equal with the concentration of hydrogencarbonate ion produced by fermentation and the amount of dissolved carbon dioxide in digestion liquor is less than $1 \%$ of the gas produced.

Combined these results with the experimental observation that the heat pretreatment of the raw wastewater did not have significant effects on the methane content in the gas produced, it is speculated that the difference between the measured and estimated results are due to different methanogenic pathways occurring in the high-load thermophilic methane fermentations in the literatures and the mesophilic methane fermentation examined in the study $^{8)}$. Because of the unique reactor design and operational patterns, SRT that was 
Table 6 Measured and calculated gas production and $\mathrm{CH}_{4}$ content in biogas

\begin{tabular}{|c|c|c|c|c|c|c|c|c|c|}
\hline \multirow[b]{3}{*}{ Pretreatment } & \multicolumn{3}{|c|}{ This study } & \multicolumn{6}{|c|}{ Sasaki et al. ${ }^{6)}$} \\
\hline & \multicolumn{2}{|c|}{ Measured } & \multirow[b]{2}{*}{$\begin{array}{c}\text { Calcu- } \\
\text { lated }\end{array}$} & \multicolumn{5}{|c|}{ Measured } & \multirow[b]{2}{*}{$\begin{array}{l}\text { Calcu- } \\
\text { lated }\end{array}$} \\
\hline & $\begin{array}{l}\text { With } \\
\text { heat } \\
\text { pretre- } \\
\text { atment }\end{array}$ & $\begin{array}{c}\text { No } \\
\text { heat } \\
\text { pretre- } \\
\text { atment }\end{array}$ & & \multicolumn{5}{|c|}{$\begin{array}{l}\text { Synthetic municipal solid waste } \\
\qquad\left(+\mathrm{Ni}^{2+}, \mathrm{Co}^{2+}, \mathrm{Fe}^{2+}\right)\end{array}$} & \\
\hline Temperature of fermentation reactor & \multicolumn{3}{|c|}{ Mesophilic } & \multicolumn{6}{|c|}{ Thermophilic } \\
\hline Molecular formula of wastewater & \multicolumn{3}{|c|}{$\mathrm{C}_{11} \mathrm{H}_{20} \mathrm{O}_{6} \mathrm{~N}$} & \multicolumn{6}{|c|}{$\mathrm{C}_{17} \mathrm{H}_{29} \mathrm{O}_{10} \mathrm{~N}$} \\
\hline Volumetric loading rate $\left(\mathrm{kg}-\mathrm{VS} / \mathrm{m}^{3} /\right.$ day $)$ & \multicolumn{2}{|c|}{2.53} & & 2.95 & 5.91 & 8.83 & 12.5 & 17.6 & \\
\hline Gas production $\left(\mathrm{m}^{3} / \mathrm{kg}-\mathrm{VS}_{\text {remove }}\right)$ & 1.09 & 0.97 & 0.85 & 0.94 & 0.95 & 0.94 & 0.86 & 1.02 & 0.88 \\
\hline $\mathrm{CH}_{4}$ content in biogas $(\%)$ & 68 & 68 & 61 & 57.4 & 57.5 & 58.3 & 59.0 & 59.1 & 57.8 \\
\hline
\end{tabular}

longer than HRT (29.4 days) was realized in the study and could have resulted in the different microbial communities within the reactor. Additional investigation on microbial communities occurring in methanogenic consortia is needed for further understanding of the processes.

The results that the gas production yield and methane content observed in the study were greater than the theoretical values based upon the approximate molecular formula and stoichiometric equations established for the thermophilic system imply the mesophilic system with heat pretreatment is indeed effective.

Effects of heat pretreatment on the energy recovery The trial calculations were made on the energy balance in the mesophilic methane fermentation of food refuse with and without heat pretreatment during the winter season. A hypothetical reactor of the effective volume of $3000 \mathrm{~m}^{3}$ is assumed for the calculations. The reactor, which is fed with food refuse at the TS volumetric loading rate of $3 \mathrm{~kg}-\mathrm{TS} / \mathrm{m}^{3} / \mathrm{day}$, is operated in the same manners as the continuous experiment reactor. Other calculation conditions are $75 \%$ of moisture content in food refuse, the VS/TS ratio of 0.85 , and the $\mathrm{TS}$ concentration in the raw water of $9.0 \%$ after the dilution. The specific heat of food refuse was assumed to be $4.184 \mathrm{~kJ} / \mathrm{kg} /{ }^{\circ} \mathrm{C}$, and heat loss during heating with direct steam injection was assumed to be $50 \%$ of the total heat input. The temperature of the food refuse and dilution water in winter was assumed to be $8^{\circ} \mathrm{C}$, and the heat loss from the methane fermentation reactor in winter was set to $3 \%$ of the heat value of the liquid in the reactor ${ }^{9)}$. Using the same result as this experiment, the gas production per influent VS with and without heat pretreatment were set to $0.69 \mathrm{~m}^{3}-\mathrm{VS} / \mathrm{kg}$ and $0.82 \mathrm{~m}^{3}-\mathrm{VS} / \mathrm{kg}$, respectively. The methane content in biogas was set to $68 \%$, and the heat value of generated gas was set to $24.3 \mathrm{MJ} / \mathrm{m}^{3}$. The electric power production efficiency and the heat collection efficiency of the gas generation were set to $35 \%$ and $45 \%$, respectively. The following two cases were compared:

(1): The food refuse is diluted first, then heated by direct steam. The thermal energy of the pretreated raw wastewater is used to maintain the reactor temperature at $35^{\circ} \mathrm{C}$.

(2): The food refuse is heated by direct steam first, then diluted by water to prepare the raw wastewater. The pretreated raw wastewater is fed to the reactor maintained at $35^{\circ} \mathrm{C}$ by a heat source.

The calculated results indicate that the recoverable electric power and thermal energy in both cases (1) and (2) are greater than those without pretreatment, however, available heat energy in the case (1) is less than that in the case (2) because greater thermal energy is required to heat the raw wastewater to $100^{\circ} \mathrm{C}$ before the fermentation (Table 7).

\section{CONCLUSIONS}

With the heat pretreatment, the VS removal efficiency was improved significantly and the gas production per influent VS 
Table 7 Trial calculation of heat balance

\begin{tabular}{|c|c|c|c|c|}
\hline \multirow{2}{*}{ Item } & \multicolumn{2}{|c|}{ With heat pretreatment } & \multirow{2}{*}{$\begin{array}{l}\text { No heat } \\
\text { pretreat- } \\
\text { ment }\end{array}$} & \multirow{2}{*}{ Remark } \\
\hline & Case (1) & Case $(2)$ & & \\
\hline Effective volume of reactor $\left(\mathrm{m}^{3}\right)$ & \multicolumn{3}{|c|}{3,000} & \\
\hline TS volumetric loading rate $\left(\mathrm{kg}-\mathrm{TS} / \mathrm{m}^{3} /\right.$ day $)$ & \multicolumn{3}{|c|}{$3.0 \quad\left(2.55^{* 1}\right)$} & \multirow{2}{*}{$\mathrm{VS} / \mathrm{TS}=0.85$} \\
\hline Influent TS (kg-TS/day) & \multicolumn{3}{|c|}{$9,000 \quad\left(7,650^{* 2}\right)$} & \\
\hline \multicolumn{5}{|l|}{ Raw wastewater condition } \\
\hline Food refuse (t/day) & \multicolumn{3}{|c|}{36} & TS : $25 \%$ \\
\hline Dilution water ( $\mathrm{t} /$ day) & \multicolumn{3}{|c|}{64} & \\
\hline Raw wastewater ( $\mathrm{t} /$ day) & \multicolumn{3}{|c|}{100} & TS : $9 \%$ \\
\hline \multicolumn{5}{|c|}{ Calculation - Required heat for the heat pretreatment and raw water heating } \\
\hline Total mass (t/day) & 100 & 36 & 100 & \multirow{4}{*}{$\begin{array}{l}\text { The temperature of food waste and } \\
\text { the dilution water: } 8^{\circ} \mathrm{C} \\
\text { Specific heat of food waste } \\
\quad: 4.184 \mathrm{~kJ} / \mathrm{kg} / \mathrm{C}\end{array}$} \\
\hline Temperature rise $\left({ }^{\circ} \mathrm{C}\right)$ & 92 & 92 & 27 & \\
\hline Heat loss $(\%)$ & 50 & 50 & 20 & \\
\hline Required heat (MJ/day) & 57,739 & 20,786 & 13,556 & \\
\hline \multicolumn{5}{|c|}{ Calculation - Heat loss from fermentation reactor and required heat for maintaining the reactor at $35^{\circ} \mathrm{C}$} \\
\hline Heat loss (MJ/day) & 13,180 & 13,180 & 13,180 & \multirow{2}{*}{$\begin{array}{l}3 \% \text { of heat volume of the liquid } \\
\text { in the reactor }\end{array}$} \\
\hline Required heat (MJ/day) & 0 & 13,180 & 13,180 & \\
\hline \multicolumn{5}{|c|}{ Calculation - Heat value of produced gas } \\
\hline Gas production $\left(\mathrm{m}^{3} / \mathrm{kg}-\mathrm{VS}_{\text {Influent }}\right)$ & 0.82 & 0.82 & 0.69 & The experimental results \\
\hline Produced biogas $\left(\mathrm{m}^{3} /\right.$ day $)$ & 6,273 & 6,273 & 5,279 & Methane content: $68 \%$ \\
\hline Heat value of produced gas (MJ/day) & 152,434 & 152,434 & 128,280 & Calorific value of biogas: $24.3 \mathrm{MJ} / \mathrm{m}^{3}$ \\
\hline \multicolumn{5}{|c|}{ Calculation - Recoverable electric power } \\
\hline Amount of power generation ( $\mathrm{kWh} /$ day $)$ & 14,820 & 14,820 & 12,470 & $35 \%$ of heat value of produced gas \\
\hline \multicolumn{5}{|c|}{ Calculation - Recoverable heat capacity and Available remaining heat capacity } \\
\hline Recoverable heat capacity (MJ/day) & 68,595 & 68,595 & 57,726 & $45 \%$ of heat value of produced gas \\
\hline \multicolumn{5}{|l|}{ Required heat } \\
\hline Heat pretreatment and Raw water heating (MJ/day) & 57,739 & 20,786 & 13,556 & \\
\hline Required heat for the reactor (MJ/day) & 0 & 13,180 & 13,180 & \\
\hline Remaining heat capacity (MJ/day) & 10,856 & 34,629 & 30,990 & \\
\hline
\end{tabular}

${ }^{* 1} \mathrm{VS}$ volumetric loading rate $\left(\mathrm{kg}-\mathrm{VS} / \mathrm{m}^{3} /\right.$ day $)$

${ }^{* 2}$ Influent VS (kg-VS/day)

increased by $19 \%$ in the continuous experiment. The VS loading rate and HRT were $2.53 \mathrm{~kg}-\mathrm{VS} / \mathrm{m}^{3} /$ day and 29 days, respectively. The methane contents of the gas produced with and without pretreatment were the same at $68 \%$. These experimental results suggest that a fraction of large molecules in the raw wastewater could not be hydrolyzed in mesophilic fermentation, but some of these large molecules were converted to smaller molecules by the heat pretreatment and had resulted in the enhanced gas production yield.

With the heat pretreatment, the methane yield, which is the product of gas production and methane content, and the carbon conversion efficiency were improved noticeably. It has been shown that the methane yield and the carbon conversion efficiency in the mesophilic methane fermentation with the heat pretreatment could be greater than those in the high-load thermophilic methane fermentation.

The gas production yield and methane content observed in the experiments with the pretreatment were greater than the theoretical values estimated in thermophilic fermentation by an approximate molecular 
formula and stoichiometric equations. This implies that mesophilic fermentation with heat pretreatment could be more effective than thermophilic fermentation.

The trial calculation on the energy balance showed that the electric power recoverable and the available thermal energy could be increased by the heat pretreatment. Mesophilic fermentation could be advantageous from the energy recovery point of view, if combined with the heat pretreatment on the raw wastewater, which leads to the eventual reduction in $\mathrm{CO}_{2}$ emission from treatment and disposal of organic wastes.

Further studies are necessary to understand better the microbial communities occurring in methanogenic processes and the effects of operational conditions on mesophilic methanogenesis. Thorough these studies, establishment of an efficient mesophilic methane fermentation system with higher loading rate than the conventional systems would be possible in the future.

\section{ACKNOWLEDGMENTS}

The study was conducted as a part of the research project "Development of the technology of the resource recovery system such as a process to manufacture high-valueadded livestock feed and so on from food waste" jointly undertaken by Yanmar Agricultural Equipment Co., LTD., Kushiro Technical Research Co., LTD., Moriplant Co., LTD., Cosmo Co., LTD., and Takuma Co., LTD.. The research project was one of the food recycling technology development projects pursued by Food Marketing Research \& Information Center and supported by the Ministry of Agriculture, Forestry and Fisheries of Japan.

We would like to express our sincere gratitude to all the people who have cooperated with us and made great contributions in the research works.

\section{REFERENCES}

1 ) Li, Y., Sasaki, H., Torii, H., Okuno, Y., Seki, K., and Kamigochi, I.: Comparison between mesophilic and thermophilic high solids anaerobic digestion in treating the organic fraction of municipal solid waste, Environ. Eng. Res., 36, 413421 (1999) (in Japanese)

2 ) Li, Y., Sasaki, H., Okuno, Y., Seki, K., and Kamigochi, I.: Effect of the influent TS concentration on high solid thermophilic methane fermentation of organic fraction of municipal solid waste, Environ. Eng. Res., 35, 29-39 (1998) (in Japanese)

3 ) Japanese Standards Association (ed.) : JIS Handbook (Environmental Technology II), Japanese Standards Association, pp439-442 (2003) (in Japanese)

4 ) Japanese Environmental Agency: Official notification No.95 - The analytical methods of the quality of wastes - (1977) (in Japanese)

5 ) Ikbal, Tang, Y., Shigematsu, T., Morimura, S., and Kida, K.: Methanogenic activity and repression of hydrogen sulfide evolved during high rate thermophilic methane fermentation of municipal solid waste, Japanese J. Wat. Treat. Biol., 39(1), 17-24 (2003)

6 ) Sasaki, H., Li, Y., Seki, K., and Kamigochi, I.: Effects of hydraulic retention time and loading rate on high-solids thermophilic methane fermentation of the organic fraction of municipal solid waste, J. Jpn. Soc. Water Environ., 22(12), 983-989 (1999) (in Japanese)

7 ) Okuno, Y., Li, Y., Sasaki, H., Seki, K., and Kamigochi, I.: Influence of the sludge ratio on the high-solids thermophilic methane fermentation of the organic fraction of municipal solid waste and bio-sludge, J. Jpn. Soc. Waste Manag. Experts, 14(1), 27-35 (2003)(in Japanese)

8 ) Kida, K., Shigematsu, T., Kijima, J., Numaguchi, M., Mochinaga, Y., Abe, N., and Morimura, S.: Influence of $\mathrm{Ni}^{2+}$ and $\mathrm{Co}^{2+}$ on methanogenic activity and the amounts of coenzymes involved in methanogenesis, J. Biosci. Bioeng., 91(6), 590-595 (2001)

9 ) Ogawa, Y., Fujita, M., and Nakagawa, Y.: Analysis of the operation data of a methane fermentation facility that treats manure and tofu refuse, J. Jpn. Soc. Waste Manag. Experts, 14(5), 258-267 (2003) (in Japanese)

(Submitted 2004. 6. 25)

(Accepted 2004. 9. 28) 